\title{
IDENTIFIKASI KESIAPAN GURU KELAS DALAM MELAKSANAKAN LAYANAN BK DI SD
}

\author{
Ayong Lianawati \\ Program studi Bimbingan dan Konseling Universitas PGRI Adi Buana Surabaya \\ ayonglianawati17@gmail.com
}

\begin{abstract}
Abstrak
Layanan BK di SD dibutuhkan sebagai upaya untuk mengembangkan sikap dan kebiasaan belajar yang baik agar siswa dapat menjadi individu yang mandiri. Berbagai kebijakan dikeluarkan untuk menegaskan kewajiban guru kelas melaksanakan layanan BK di SD, namun tidak diketahui secara faktual kesiapan guru kelas dalam menjalankan peran dan fungsi tersebut. Oleh karena itu penelitian bertujuan untuk mengidentifikasi kesiapan guru kelas melalui pemahaman terhadap aktivitas yang telah dilakukan dan termasuk pada tugas dan fungsi sebagai pembiming. Penelitian dilakukan di SD Pandan Krajan II, dengan mengggunakan metode deskriptif kualitatif. Data diperoleh dengan mengggunakan wawancara. Hasil penelitian menunjukkan kesiapan guru kelas dalam melaksanakan layanan dirasa kurang dalam perencanaan program yang didasari asesmen, dan kompetensi dalam strategi konseling. Namun dalam melakukan layanan tidak langsung (melalui media) guru kelas diprediksi akan lebih optimal menggunakan kegiatan literasi. Penelitian merekomendasikan guru kelas harus mendapatkan pelatihan khusus dalam asesmen, art \& expressive therapy sebagai strategi konseling, dan keterampilan komunikasi empatik agar memudahkan siswa untuk terbuka.
\end{abstract}

Kata Kunci: BK, Guru, SD.

\section{PENDAHULUAN}

Bimbingan dan konseling di Sekolah Dasar (SD) saat ini masih sekedar isu, dan minim praktik di lapangan. Padahal secara legalitas sudah ditegaskan dalam Permendikbud Nomor 111 tahun 2014, tentang Bimbingan dan Konseling pada Pendidikan Dasar dan Pendidikan Menengah. Pada tahun 2016 pun panduan operasional layanan BK di SD sudah diterbitkan.
Secara global, berbagai penelitian menunjukkan bahwa layanan konseling dan layanan kesehatan mental mampu memberikan kontribusi dalam peningkatan prestasi siswa di sekolah dasar (Sink, 2008). Pendapat tersebut didasari oleh penelitian yang dilakukan American School Counselor Association (ASCA) selama 20 tahun terakhir.

Kebutuhan akan layanan BK di SD didasari oleh konteks perkembangan siswa yang berada pada masa pertumbuhan, masa pengenalan dan 
pembentukan. Oleh karena itu tuntutan keberadaan layanan BK di SD memfasilitasi siswa dalam melatih keterampilannya dalam kehidupan sehari-hari, serta membentuk sikap dan kebiasaan positif, dengan tujuan akhirnya adalah kemandirian dalam bertindak dan berprilaku.

Hasil kajian Setianingsih (2016) menunjukkan beberapa permasalahan siswa SD yang lazim terjadi seperti berbohong, meninggalkan kelas tanpa izin, mencontek, kurang disiplin, dan lain sebagainya. Hal tersebut disebabkan karena sikap dan cara belajar yang tidak tepat, sehingga bimbingan dan konseling diperlukan untuk mengembangkan sikap belajar. Bimbigan dan konseling perlu diintergrasikan dengan kegiatan belajar mengajar, yang berupa pembentukan kebiasaan dan sikap belajar yang baik.

Dalam Panduan Operasional Penyelenggaraan BK di SD (POP BKSD), terdapat berapa alternatif penyelenggara layanan BK di SD antara lain: 1) Guru BK atau konselor di SD ditugaskan pada setiap sekolah, 2) Guru BK tingkat gugus yang berkantor di sekolah induk ditetapkan oleh Dinas Pendidikan Kabupaten/Kota. dan 3) Guru BK dapat ditugaskan di UPTD Pendidikan atau unit pendidikan yang setingkat (Farozin et.al, 2016). Sayangnya, secara teknis belum sepenuhnya diturunkan pada kebijakan teknis kepada dinas pendidikan di daerah, hingga unit sekolah, sehingga penyelenggara layanan BK sampai saat ini dibebankan kepada guru/wali kelas.

Implikasinya guru kelas ditantang untuk mempersiapkan diri dengan tugas tambahan sebagai pembimbing, yang nantinya berdampak kepada pengembangan kompetensi sebagai pembimbing. Intergrasi layanan $\mathrm{BK}$ dengan tugas guru kelas ditegaskan dalam SK Menpan No. 084/1993 pasal 3, yaitu guru kelas harus menyusun, melaksanakan, mengevaluasi, serta menganalisis program bimbingan yang dilakukan kepada siswa yang menjadi tanggung jawabnya (Mulyadi, 2015).

Dalam POP BK-SD disebutkan secara rinci beberapa tugas yang harus dilaksanakan guru kelas sebagai pembimbing.

1. Melakukan pemahaman terhadap peserta didik secara mendalam (asesmen)

2. Menyusun rencana operasional dalam penyelenggarakan layanan dasar

3. Melakukan layanan langsung (konseling, bimbingan klasikal, bimbingan kelompok, alih tangan kasus, kolaborasi dan konsultasi, home visit, advokasi, dan case conference).

4. Pengembangan media layanan (liflet, kepustkaan,pengembangan media inovatif).

5. Melakukan evaluasi dan tindak lanjut terhadap hasil layanan BK. 
Diantara tugas-tugas tersebut mungkin ada yang sudah dan belum dilakukan, ataupun dikuasai oleh guru kelas. Sehingga dalam penelitian ini dilakukan identifikasi untuk menentukan kesiapan guru kelas dalam menyelenggarakan layanan BK di SD.

\section{RUMUSAN MASALAH}

Berdasarkan pemaparan pada pendahuluan dapat dirumuskan bahwa masalah dalam penelitian adalah "bagaimanakah kesiapan guru kelas dalam menjalankan layanan BK di SD, berdasarkan tugas dan aktivitas membimbing yang telah dilakukan"

\section{METODE}

Metode deskriptif kualitatif digunakan dalam penelitian ini, sebagai agar informasi yang diperoleh bersifat faktual, real dan mendalam. Sebagai metode yang didasari oleh filsafat postositivisme, metode kualitatif bermanfaat untuk meneliti sebuah kondisi yang alamiah (Sugiyono, 2008)

Data penelitian diperoleh melalui wawancara terhadap guru kelas di SD Pandan Krajan II. Penggunaan wawancara dilakukan dalam satu sesi FGD berasa para guru, yang dihadiri juga oleh kepala sekolah.

Wawancara difokuskan untuk menggali kebiasaan dan pengelolan kelas yang dilakukan oleh guru kelas, berkaitan dengan tanggungjawab tugas guru kelas sebagai pembimbing. Hasil wawancara dipetakan dalam bentuk tabel perbandingan dengan peran guru kelas dalam POP BK-SD.

\section{HASIL DAN PEMBAHASAN Hasil}

A. Pemahaman terhadap siswa

Dalam memahami siswa, kecenderungan guru kelas melakukan observasi pada perilaku siswa selama pembelajaran berlangsung. Wawancara akan dilakukan jika terjadi sesuatu di kelas, misalkan pertengkaran, tidak mengerjakan tugas, dan membolos. Berbeda dengan guru kelas 5 \& 6, guru kelas 1 \&2 menjelaskan jika mereka lebih banyak berbincang dengan orang tua, karena siswa kelas bawah masih malu malu jika ditanya, oleh karena itu dalam mendalami siswa mereka lebih banyak beribincang dengan orang tua tentang kebiasaan siswa di rumah.

Secara umum, guru lebih banyak menanyakan tentang 1) kebiasaan belajar di rumah, 2) keseharian siswa di rumah, dan 3) interaksi siswa di kelas. Informasi tersebut diperoleh ketika siswa melakukan perilaku bermasalah.

Selain di kelas, momen lain yang digunakan oleh guru kelas untuk memahami siswa adalah ketika pertemuan orang tua di akhir semester. Dalam pertemuan orang tua guru berkesempatan untuk bertanya yang lebih dalam mengenai keseharian siswa di rumah. 
B. Perencanaan operasional layanan yang terintergrasi dengan RPP

Guru-guru satu suara bahwa mereka tidak paham tentang cara mengintergrasikan layanan pada RPP. Menurut mereka, dalam menyusun RPP akan mengikuti kurikulum dan silabus yang baku dari dinas.

Adapun pengembangan diri siswa dirumuskan dalam poin pengembangan karakter pada RPP. Hal itu pun biasanya sudah ada pada panduan buku ajar yang digunakan.

\section{Layanan Langsung}

Pelakasanaan bimbingan secara langsung yang pernah dilakukan guru kelas biasanya adalah pemberian informasi tentang aturan dan pola hidup sehari hari. Di kelas atas guru kelas terbiasa melakukan kegiatan diskusi bersama siswa mengenai topik kehidupan sehari hari.

Dalam pengentasan masalah, biasanya guru memanggil langsung siswa yang bersangkutan dengan orang tua/wali. Menurut guru, metode itu dipilih karena perubahan anak tidak akan lepas dari kesehariannya di rumah, sehingga dibutuhkan peran dan kerjasama orang tua. Pemanggilan orang tua dilakukan jika siswa sudah melakukan perilaku yang sama berulang kali, biasanya siswa diberikan tiga kali kesempatan.

Guru-guru mengakui bahwa mereka tidak memahami cara melakukan konseling yang baik dan benar. Terlebih melakukan konseling terhadap satu kelompok siswa dengan metode yang sesuai dengan teori konseling.

D. Layanan melalui media

Di SD Pandan Krajan II dilakukan kegiatan literasi setiap 15 menit di jam pertama pelajaran. Siswa ditugaskan untuk menceritakan buku yang dia baca di rumah, kemudian ditanggapi oleh guru dan siswa lain. Namun kegiatan tersebut hanya untuk kelas 4-6.

Media lain yang digunakan di kelas adalah poster. Siswa dapat membaca poster yang ditempel di kelas berupa etika, sopan santun, dan kalimatkalimat motivasi.

E. Evaluasi pelaksanaan bimbingan

Evaluasi yang dilakukan guru biasanya menggunakan poin pelanggaran, jika siswa banyak melakukan pelanggaran maka akan ada pengurangan skor. Selain itu guru membuat deskripsi karakter setiap anak pada buku laporan. Namun guru guru tidak tahu apakah termasuk pada evaluasi bimbingan atau bukan.

\section{Pembahasan}

Berdasarkan hasil wawancara, dapat dipetakan seperti pada tabel 1 di bawah ini. 
Tabel 1

Pemetaan identifikasi peran dan fungsi BK yang telah dilakukan guru kelas

\begin{tabular}{|c|c|c|c|}
\hline No & $\begin{array}{l}\text { Aspek } \\
\text { Peran }\end{array}$ & Kegiatan & $\begin{array}{c}\text { Kegiatan } \\
\text { Bimbingan }\end{array}$ \\
\hline \multirow[t]{2}{*}{1} & \multirow[t]{2}{*}{$\begin{array}{l}\text { Memahami } \\
\text { Peserta } \\
\text { didik }\end{array}$} & $\begin{array}{l}\text { Mengobservasi } \\
\text { siswa saat proses } \\
\text { belajar }\end{array}$ & Observasi \\
\hline & & $\begin{array}{l}\text { Memanggil siswa } \\
\text { dan } \\
\text { Berbincang } \\
\text { dengan orang tua } \\
\text { mengenai } \\
\text { kebiasaan belajar } \\
\text { dan keseharia } \\
\text { siswa }\end{array}$ & $\begin{array}{l}\text { Wawancar } \\
\text { a }\end{array}$ \\
\hline 2 & $\begin{array}{l}\text { Intergra } \\
\text { si } \\
\text { Operasiona } \\
1 \text { dengan } \\
\text { RPP }\end{array}$ & $\begin{array}{l}\text { Memasukan poin } \\
\text { pengembangan } \\
\text { karakter pada RPP } \\
\text { berdasarkan buku } \\
\text { ajar dan silabus }\end{array}$ & $\begin{array}{l}\text { Belum } \\
\text { terintergras } \\
\mathrm{i} \text { dengan } \\
\text { standar } \\
\text { kompetens } \\
\mathrm{i}\end{array}$ \\
\hline \multirow[t]{2}{*}{3} & \multirow[t]{2}{*}{$\begin{array}{c}\text { Layana } \\
\text { n Langsung }\end{array}$} & $\begin{array}{l}\text { Berdiskusi dengan } \\
\text { topik kehidupan } \\
\text { sehari hari }\end{array}$ & $\begin{array}{l}\text { Bimbingan } \\
\text { kelompok }\end{array}$ \\
\hline & & $\begin{array}{l}\text { Pengentasan } \\
\text { masalah } \\
\text { melibatkan orang } \\
\text { tua }\end{array}$ & Kolaborasi \\
\hline \multirow[t]{2}{*}{4} & \multirow[t]{2}{*}{$\begin{array}{l}\text { Layanan } \\
\text { menggunak } \\
\text { an media }\end{array}$} & $\begin{array}{l}\text { Melakukan literasi } \\
\text { di } 15 \text { menit jam } \\
\text { pelajaran pertama }\end{array}$ & $\begin{array}{l}\text { Biblio/kepu } \\
\text { stakaan }\end{array}$ \\
\hline & & $\begin{array}{l}\text { Menempel poster } \\
\text { tentang etika, } \\
\text { sopan santun, dan } \\
\text { kalimat motivasi }\end{array}$ & Poster \\
\hline 5 & $\begin{array}{l}\text { Evaluasi } \\
\text { kegiatan } \\
\text { bimbingan }\end{array}$ & $\begin{array}{l}\text { Menggunakan } \\
\text { skor dan } \\
\text { Memberikan } \\
\text { deskripsi individu }\end{array}$ & $\begin{array}{l}\text { Bukan } \\
\text { evaluasi } \\
\text { layanan } \\
\text { bimbingan }\end{array}$ \\
\hline
\end{tabular}

Berdasarkan pemetaan tersebut kesiapan guru kelas dalam menjalankan layanan BK di SD masih banyak yang harus dipersiapkan. Perhatian utama dari hasil wawancara adalah pengembangan program dan evaluasi layanan.

Dalam mengintergrasikan layanan BK dengan RPP, idealnya berdasarkan hasil asesmen yang dilakukan. Namun sayangnya asesmen yang dilakukan bersifat insidental.

Untuk mempermudah guru kelas dalam pengembangan materi bimbingan, ada baiknya dilakukan secara bersama sama antar guru kelas bahkan dengan pimpinan sekolah. Silitonga et. al. (2014) mendeskripsikan kegiatan perencanaan bimbingan di SDN 2 Rowosari melibatkan kepala sekolah, guru kelas dan guru bidang studi. Dalam pertemuan tersebut disampaikan profil dan karakteristik pribadi siswa yang perlu dikembangkan secara maksimal, sepertimematuhi tata tertib sekolah serta berakahlak mulia, demokratis dan juga bertanggungjawab.

Kelengkapan data mengenai siswa merupakan modal utama guru kelas dalam memahami siswa secara mendalam. Terdapat tiga cara yang dilakkan dalam memahami siwa yaitu menggunakan tes, wawancara, dan observasi. Dalam POP BK-SD disebutkan jika guru kelas memiliki keterbatasan dalam melakukan tes, hendaknya dapat melakukan 1) mengumpulkan hasil belajar, 2) penyebaran angket, 3) studi dokumentasi, dan 4) catatan anekdot. 
Peluang terbesar guru kelas dalam memanfaatkan asesmen untuk merencanakan kebutuhan layanan adalah dengan mengumpulkan hasil belajar. Dengan demikian akan membantu guru kelas untuk memetakan kesulitan belajar sisiwa serta mengetahui tingkat perkembangan kognitif dan psikomotorik peserta didik. Data hasil belajar, dapat diperoleh melalui tes harian, penilaian tengah semester, dan penilaian akhir semester.

Selanjutnya, berkenaan dengan kesiapan guru kelas dalam melaksanakan layanan konseling dapat dilakukan dengan mengikuti kursus/pendidikan khusus mengenai intervensi play \& expressive art therapy. Henderson (2011) berpendapat bahwa kedua intervensi tersebut merupakan strategi utama dalam konseling anak, dan dapat diintergrasikan dalam konseling keluarga seperti dengan melakukan psikodrama, family drawing, family sclupture, dan genogram. Sesuai dengan pandangan guru-guru bahwa permasalahan anak memerlukan kerjasama dan peran orang tua dalam pengentasannya.

Jika kompetensi dalam melakukan konseling tidak dimiliki guru kelas, maka langkah awal yang harus dilakukan adalah pembiasaan dalam menggunakan komunikasi yang empati dengan siswa. Hal tersbut merujuk pada POP BK di SD yang menjelaskan komunikasi empatik dan membangun relasi yang membantu merupakan keterampilan yang harus dilatih. Jika guru kelas minim pengetahuan atau kompetensi untuk melakukan proses konseling, maka perlu adanya pendampingan, sehingga memudahkan guru untuk membuat siswa nyaman, percaya dan berani menceritakan masalah yang dialaminya. Dengan demikian, posisi Guru kelas adalah sebagai pendengar yang memiliki empati, mampu memberikan nasehat dan melaksanakan referral terhadap konseli untuk melakukan konseling dengan guru bimbingan dan konseling atau konselor (Farozin et.al, 2016).

Terakhir, kesiapan utama guru kelas dalam melaksanakan layanan BK di SD dapat dioptimalkan dalam intergrasi kegiatan sekolah sebagai layanan tidak langsung. Kegiatan seperti literasi dapat dioptimalkan sebagai bibliotherapy, yang termasuk pada kegiatan layanan tidak langsung. Pengembangan tema dan aktivitas literasi yang tepat untuk mengembnagkan karakter siswa dapat disusun bersama, sehingga menjadi kurikulum bimbingan yang terstruktur dan intergratif dari kelas rendah hingga kelas atas.

\section{Simpulan}

Penelitian ini telah berhasil mengidentifikasi peluang dan tantangan dalam meningkatkan kesiapan guru kelas di SD Pandan Krajan II 
menyelenggarakan layanan BK di SD. Guru kelas masih kurang pemahaman dan kompetensi dalam pengembangan program, dan strategi layanan konseling di SD. Namun mereka memiliki peluang dalam mengembangkan layanan tidak langsung seperti melakukan bibliotherapy dan layanan melalui media poster.

\section{DAFTAR PUSTAKA}

Farozin, M., Suherman, U., Triyono, Purwoko, B., Hafina, A., Yustiana, Y. R., \& Sukmaja. (2016). Panduan Operasional Penyelenggaraan Bimbingan dan Konseling Sekolah Dasar (SD). Jakarta: Direktorat Jenderal Guru dan Tenaga Kependidikan Kementerian Pendidikan dan Kebudayaan Republik Indonesia.

Henderson , Donald A,. (2011). Counseling Children 8 Edition. USA : Brooks/ Cole

Mulyadi. (2015). Pola Umum Bimbingan dan Konseling di Sekolah Dasar (SD) dan atau Madrasah Ibtidaiyah (MI). Jurnal Tarbiyah Al-Awlad, 4(2), 408417.

Setianingsih, E. S. (2016). Peranan Bimbingan Dan Konseling Dalam Memberikan Layanan Bimbingan Belajar Di SD. Malih Peddas (Majalah Ilmiah Pendidikan Dasar), 6(1).

Silitonga, A. S., Sarjono, Y., \& Anif, S. (2014). Pengelolaan Kegiatan Bimbingan dan Konseling untuk Pembentukan Karakter Siswa Sekolah Dasar.

Sink, C. A. (2008). Elementary School Counselors and Teachers: Collaborators for Higher Student Vol.
108, No. 5. The Elementary School Journal, 445 - 458.

Sugiyono. 2008. Metode Penelitian Kuantitatif Kualitatif dan R\&D. Bandung. Alfabeta. 